\title{
Ectoparasites associated with sigmodontine rodents from northeastern Argentina
}

\author{
Marcela Lareschi ${ }^{1,2 *}$, Ekaterina Savchenko² and Mara Urdapilleta ${ }^{2,3}$ \\ ${ }^{1}$ Centro de Estudios Parasitológicos y de Vectores (CONICET-UNLP). Bv. 120 s/n e/ 60 y 64, 1900, La Plata, Argentina. Email: \\ mlareschi@cepave.edu.ar \\ ${ }^{2}$ Consejo Nacional de Investigaciones Científicas y Técnicas (CONICET), Argentina. Email: ekaterina@cepave.edu.ar \\ ${ }^{3}$ Instituto Nacional de Medicina Tropical (INMeT; Ministerio de Salud y Desarrollo Social de la Nación), Jujuy y Neuquén s/n, 3370 , \\ Misiones, Argentina. Email: bupamara@gmail.com \\ * Corresponding author
}

\begin{abstract}
Usually sigmodontine rodents (Cricetidae) are associated with a variety of ectoparasites. However, the studies in northeastern Argentina are scarce. Herein we analyze the ectoparasite component communities associated with four species of sigmodontines in the south of the Province of Misiones. In total, 835 ectoparasites were collected from the 97 rodents examined: 782 mites (Acari, Mesostigmata; $S=7 ; P=78.35 \%$; $M A=8.06$ ), 50 fleas (Hexapoda, Siphonaptera; $S=2 ; P=21.65 \% ; M A=0.53$ ), and two ticks (Acari, Ixodida; $S=1 ; P=2.06 \% ; M A=0.02, P<0.005$ ). The following five species are mentioned for the first time for the northeastern: Androlaelaps rotundus, Gigantolaelaps wolffsohni, Laelaps manguinhosi, L. paulistanensis, and Polygenis ( $P$.) tripus, increasing the biodiversity known for the area. A tendency toward host aggregation was observed for most of the ectoparasites. Out of 10 ectoparasite species identified in the present study, five were collected from a unique host species, and so, species richness varied between three and four in every component community. Since some of the ectoparasites identified may play a role as vectors of pathogens, the obtained results contribute to a better understanding of the ectoparasite-host relationship, which may have epidemiological implications.

Por lo general, los roedores sigmodontinos (Cricetidae) están asociados con una variedad de ectoparásitos. Sin embargo, los estudios en el noreste argentino son escasos. Aquí analizamos las comunidades componentes de ectoparásitos asociados con sigmodontinos en el sur de la Provincia de Misiones. En total, se recolectaron 835 ectoparásitos de los 97 roedores examinados: 782 ácaros (Acari, Mesostigmata; $\mathrm{S}=7$; $\mathrm{P}$ $=78.35 \% ; M A=8.06$ ), 50 pulgas (Hexapoda, Siphonaptera; $\mathrm{S}=2 ; \mathrm{P}=21.65 \% ; \mathrm{MA}=0.53$ ), y dos garrapatas (Acari, Ixodida; $\mathrm{S}=1 ; \mathrm{P}=2.06 \%$; $\mathrm{MA}=0.02, P<0.005)$. Las cinco especies siguientes se mencionan por primera vez para el noreste: Androlaelaps rotundus, Gigantolaelaps wolffsohni, Laelaps manguinhosi, L. paulistanensis y Polygenis (P.) tripus, y aumentan el conocimiento sobre la biodiversidad del área. Se observó una tendencia hacia la agregación para la mayoría de los ectoparásitos. De las 10 especies de ectoparásitos identificadas en el presente estudio, cinco se recolectaron de una especie hospedadora única, por lo que la riqueza específica varió entre tres y cuatro en cada comunidad componente. Dado que algunos de los ectoparásitos identificados pueden jugar un rol en la transmisión de patógenos, los resultados obtenidos contribuyen a una mejor comprensión de la relación ectoparásito-hospedador, que puede tener implicaciones epidemiológicas.
\end{abstract}

Key words: Argentina; cricetids; ectoparasites; fleas; mites; rodents; sigmodontines; ticks.

(C) 2019 Asociación Mexicana de Mastozoología, www.mastozoologiamexicana.org

\section{Introduction}

Sigmodontine rodents (Cricetidae) are a fundamental component of the fauna of South America, representing about $20 \%$ of the species of mammals inhabiting the subcontinent. Seven families of rodents are represented within the Misiones Province, situated in the far northeast of Argentina, limiting with Paraguay and Brazil (Patton et al. 2015; Lanzone et al. 2018). An analysis of the species richness considering only the rodents of the family Cricetidae (Sigmodontinae), indicates that spatially the greatest values are concentrated towards the central-southern part of the province, in a region where the Bosque Atlántico Interior overlap with the ecoregion of the Fields and Malezales. The high richness in the area may be related to the occurrence of a greater environmental heterogeneity with the presence of forest-dwelling rodents and others adapted to pasture environments. In addition, out of the four endemic species of rodents reported for the province of Misiones, one (Akodon philipmyersi Pardiñas, D'Elía, Cirignoli and Suárez) is reported for the ecoregion of the Fields and Malezales (Galliari and Goin 1993; Pardiñas et al. 2005; Patton et al. 2015; Lanzone et al. 2018).

Usually sigmodontine rodents are associated with a variety of ectoparasites, such as mites, ticks and fleas. A parasite component community represents all of the parasites associated with some subset of a host species, such as a population (Bush et al. 1997). Host-parasite associations are the result of evolutionary and ecological processes, since individuals in a rodent community or population vary in ways that may affect their interactions with their parasites. For example, host specimens may vary in their sex, age, physiology, morphology, ethology, ecology, etc., and all these features may influence their ectoparasite populations (Marshall 1981; Kim 1985; Morand et al. 2006; Krasnov 2008). In addition, some ectoparasites are epidemiologically important because they are involved in the transmission of pathogens that cause diseases in humans and domestic and wild animals, and whose reservoirs are rodent hosts. 
Studies on component communities of ectoparasites of sigmodotines are not abundant worldwide, and Latin America is not an exception. Most of the studies were conducted in Brazil and Argentina, and in the last country, researches were concentrated in Buenos Aires Province (Linardi et al. 1991; Barros-Battesti et al. 1998; Lareschi et al. 2007; Lareschi and Krasnov 2010; Sponchiado et al. 2015; Liljesthröm and Lareschi 2018). Despite the biological relevance of northeastern Argentina, only a few ectoparasite species have been reported associated with sigmodontines, and there are not ecological analyses characterizing ectoparasite component communities (Lareschi 2010, 2011; Lareschi et al. 2016; Pardiñas et al. 2016). Thus, the aim of our study is focused on the ecological study of the communities of ectoparasites of rodents of the subfamily Sigmodontinae in southern Misiones Province in northeastern Argentina.

\section{Materials and Methods}

Study area. The study was conducted in the south of the Misiones Province. We selected two localities situated in the southern limit of the Fields and Malezales ecoregion (Burkart et al. 1999), very close to the the Bosque Atlántico Interior, and about less than $20 \mathrm{~km}$ far from Posadas City (Figure 1). Samples were taken in Estancia Santa Inés (-27 $31^{\prime} \mathrm{S}$; $-55^{\circ} 52^{\prime} \mathrm{W}$ ) during April-2007 and May-2009 and 2018, and in the Estación Experimental del Instituto Nacional de Tecnología Agropecuaria (EEA INTA) Villa Miguel Lanús

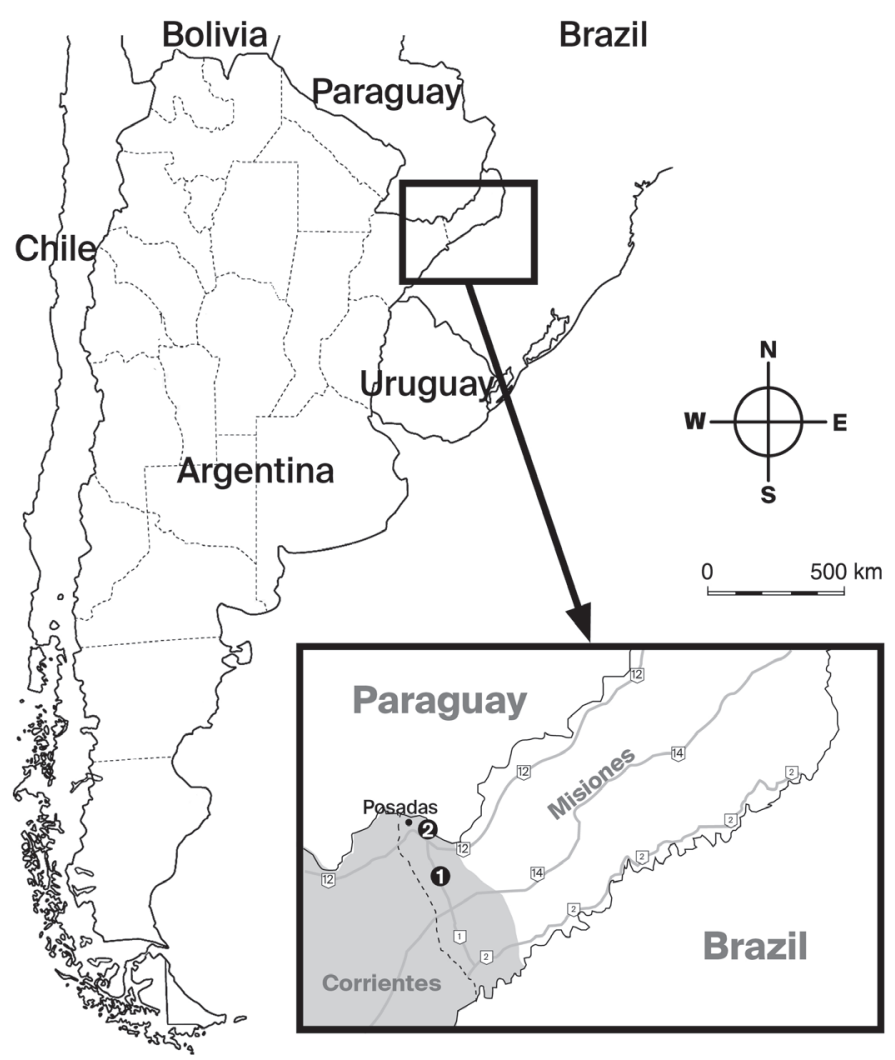

Figure 1. Sites of collection of ectoparasites. Locality 1: Estación Experimental del Instituto Nacional de Tecnología Agropecuaria (EEA INTA) Villa Miguel Lanús $\left(27^{\circ} 25^{\prime} \mathrm{S}\right.$; $\left.55^{\circ} 53^{\prime} \mathrm{W}\right)$. Locality 2: Estancia Santa Inés $\left(-27^{\circ} 31^{\prime} \mathrm{S} ;-55^{\circ} 52^{\prime} \mathrm{W}\right)$. Grey indicates the ecoregion Fields y Malezales. $\left(-27^{\circ} 25^{\prime} \mathrm{S} ;-55^{\circ} 53^{\prime} \mathrm{W}\right)$ in April, 2007. The traps were placed in dirty (not carpid) fields of yerba mate, in fields invaded by chilcas (Baccharis sp.), in Andropogon sp. grasslands, in grasslands of cuttings in low areas and in forests implanted with native species located in the surroundings of the hull of the stay.

Rodents. Ninety-seven rodents (Cricetidae: Sigmodontinae) captured alive by using Sherman traps baited with oats were examined for ectoparasites. Ulyses F. J. Pardiñas (IDEAus Centro Nacional Patagónico, Puerto Madryn, Chubut, Argentina) and Carlos Galliari (Centro de Estudios Parasitológicos y de Vectores, La Plata, Argentina) taxonomically identified the rodents as: Cricetidae, Sigmodontinae, Akodontini: Necromys lasiurus (Lund) $(n=61), A$. philipmyersi $(n=13)$, and Oxymycterus rufus Fischer $(n=1)$; Phyllotini: Calomys sp. $(n=10)$; Oryzomyini: Oligoryzomys flavescens (Waterhouse) $(n=7)$ and O. nigripes Desmarest $(n=5)$. Representative individuals of each species of rodents were deposited at the Colección de Mamíferos del Centro Nacional Patagónico (CNP; Puerto Madryn, Chubut Province, Argentina), some of them still have the field number: CNP742, CNP3041, CNP6007, CNP6020, CNP5705, and CNP4950.

Ectoparasites. The fur of the hosts was searched for ectoparasites with the use of combs, tooth brushes and forceps. The ectoparasites were preserved in $96 \%$ ethanol. For taxonomic identification, mites were cleared in lactophenol and individually mounted in Hoyer's medium; fleas were cleared by using $\mathrm{KOH}$ and mounted in Canadian balsam; ticks were identified directly under stereoscopic microscope. Ectoparasites were identified in accordance with the keys, drawings and descriptions given by Furman (1972), Smit (1987) and Martins et al. (2014). Representative specimens of ectoparasites of each species were deposited at the Colección del Departamento de Entomología, Museo de La Plata (MLP; La Plata, Argentina). The catalogue number consists of the number of the host followed by a script and the number corresponding to the individual ectoparasite; some specimens still have field numbers: MLP-CNP742-3, MLP-CNP3041-1, MLP-CNP6007-1, MLP-CNP6020-1, MLP-CNP5705-1, MLPLTU697-1/2, MLP-LTU709-1/2, and MLP-LTU717-1.

Data analyses. Since only 12 individuals of $N$. lasiurus were captured at EEA INTA, and both sites of collection are close and similar in their vegetation, data from both localities was analyzed together. Indices and parameters were calculated as follow: Ectoparasite specific richness ( $S$ $=$ number of species), Shannon specific diversity index $[\mathrm{H}$ $=-\Sigma$ (pi In pi)], equitability index $(J=H / l n S)$, mean abundance (MA = total number of individuals of a particular parasite species in a sample of a particular host species/total number of hosts of that species, including both infected and non-infected hosts) and prevalence $[\mathrm{P}=$ (number of hosts infected with one or more individuals of a particular parasite species/the number of hosts examined for that parasite species) x 100] (Begon et al. 1988; Bush et al. 1997). We tested significance $(P)$ of differences between mean 
abundances and prevalences using Fisher's exact test and Student's t-test, respectively. The variance to mean ratio (V/M) was also calculated to examine the distribution of every ectoparasite within each host species. Analyses were calculated using parasitology software Quantitative Parasitology 3.0 (Rózsa et al. 2000). Species accumulation curves were made with PAST Program (Hammer and Harper 2001), which implements the analytical solution known as "Mao's tau", with 95 percent confidence intervals. We use a matrix of presence-absence data. Species richness of ectoparasites is estimated as a function of number of samples or hosts (number of rodent individuals of the same species).

\section{Results}

A total of 834 ectoparasites were collected from the 97 rodents examined. Out of them, 782 specimens were mites (Acari, Mesostigmata), 50 were fleas (Hexapoda, Siphonaptera), and two were ticks (Acari, Ixodida). Total species richness was $\mathrm{S}=10$; and diversity was $\mathrm{H}=0.68$. In comparison, mites were highly significant more prevalent and abundant $(S=7 ; P=78.35 \% ; M A=8.06)$ than fleas $(S=2 ; P=21.65 \%$; $M A=0.53)$ and ticks $(S=1 ; P=2.06 \% ; M A=0.02, P<0.005)$.

The collected ectoparasites were identified as: Acari, Mesostigmata, Laelapidae, Laelapinae: Androlaelaps fahrenholzi (Berlese; $n=94$ ), A. rotundus (Fonseca; $n=366$ ), $A$. ulysespardinasi Lareschi $(n=204)$, Gigantolaelaps wolffsohni Oudemansi $(n=21)$, Laelaps manguinhosi Fonseca $(n=6)$, L. paulistanensis Fonseca $(n=56)$, Mysolaelaps parvispinosus Fonseca $(n=35)$; Acari, Ixodida, Ixodidae: Amblyomma ovale Koch ( $n=2$, nymphs); Hexapoda, Siphonaptera, Rhopalopsyllidae, Rohopalopsyllinae: Polygenis (Polygenis) tripus (Jordan; $n=48)$, Polygenis sp. $(n=2)$.

Ectoparasite component communities are compared in Tables 1 and 2. Oxymycterus rufus and Calomys sp. were not included, since $O$. rufus was not parasitized, and only one specimen of Calomys sp. was associated with a single flea (P. (P.) tripus). Akodon philipmyersi shows the lowest values of $\mathrm{S}, \mathrm{H}$ and J (Table1), with a remarkable dominance of $A$. ulysespardinasi (92\%; Table 2).

Table 1. Comparison of component communities of ectoparasites associated with every host species. $\mathrm{S}=$ specific richness; $\mathrm{H}=$ Shannon specific diversity; $\mathrm{J}=$ equitability index.

\begin{tabular}{rrrrr}
\hline & \multicolumn{1}{c}{$\begin{array}{c}\text { Necromys } \\
\text { lasiurus }\end{array}$} & \multicolumn{1}{c}{$\begin{array}{c}\text { Akodon } \\
\text { philipmyersi }\end{array}$} & $\begin{array}{c}\text { Oligoryzomys } \\
\text { flavescens }\end{array}$ & $\begin{array}{c}\text { Oligoryzomys } \\
\text { nigripes }\end{array}$ \\
\hline $\mathrm{S}$ & 4 & 3 & 4 & 4 \\
$\mathrm{H}$ & 0.76 & 0.31 & 1.34 & 1.02 \\
$\mathrm{~J}$ & 0.55 & 0.28 & 0.97 & 0.74 \\
\hline
\end{tabular}

Species accumulation curves considering species richness of ectoparasites as a function of number of individual hosts of each species are shown in Figures $2 \mathrm{a}-\mathrm{d}$. Although the number of host specimens of some species is low, the curve seems to stabilize for most of the species. The number of specimens of every ectoparasite species, as well as the values of mean abundance, prevalence and their distribution are shown in Table 2.

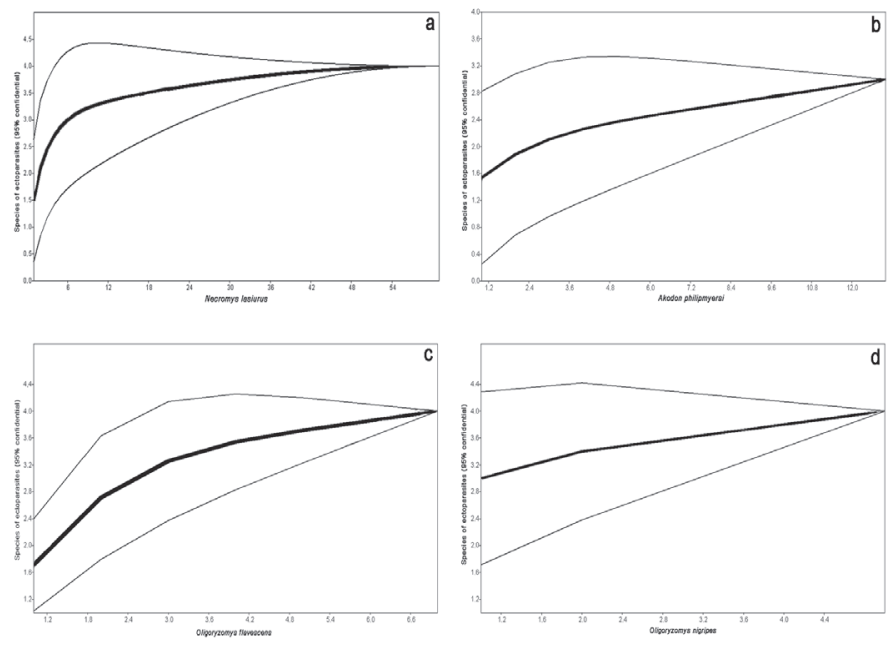

Figure 2. (a-d). Species accumulation curves considering species richness of ectoparasites as a function of number of individual hosts of each species.

Ectoparasite component communities associated with A. philipmyersi showed the highest MA (17.08), which was significantly different from the remaining ones $(P<0.05)$. On the contrary, component communities of $O$. flavescens showed the lowest MA (4.86), which differed from those of $A$. philipmyersi and $O$. nigripes $(P<0.005)$, but not from $N$. lasiurus $(P>0.05)$. Differences among total prevalences did not show significance $(P>0.05)$. Akodon philipmyersi shows the higher value of dominance $(92 \%, A$. ulysespardinasi), and O. nigripes the lowest one (35\%, M. parvispinosus). Considering those ectoparasite species associated with two or more host species (Table 2), only G. wolffsohni was significantly more abundant in $O$. nigripes (3.00) than in $O$. flavescens $(0.86 ; P<0.05)$.

When comparing ectoparasite species within every component community (Table 2), the differences observed between prevalences and mean abundances of $A$. fahrenholzi and $A$. rotundus associated with N. lasiurus; and $A$. fahrenholzi and $A$. ulysespardinasi parasitizing A. philipmyersi were highly significant $(P<0.005)$. Considering high taxa of ectoparasites, differences in prevalences and mean abundances between mites $(P=85.2 ; \mathrm{MA}=7.3)$ and fleas associated with $N$. lasiurus, were highly significant $(P<0.005)$.

When comparing ectoparasite component communities between host tribes, Akodontini vs Oryzomini, differences between prevalences ( $P=90.50$ vs $P=91.70 ; P>1)$ and mean abundances ( $M A=10.66$ vs $M A=10.82 ; P=0.92)$, were not significant. Comparing host species included in every tribe, $O$. nigripes MA (13.4) show differences highly significant from that of $O$. flavescens ( $M A=4.86 ; P<0.05)$, while differences in their prevalences were not significant $(P=100 \%$ vs $P=85 \% ; P=1)$. Results are similar when comparing $N$. lasiurus vs $A$. philipmyersi: differences in their mean abundance ( $M A=8.11$ vs $M A=17.11, P<0.005)$ were highly significant, while those in prevalences were not $(\mathrm{P}=$ $88.5 \%$ vs $P=100 ; P>1$ ). Considering all ectoparasites in every component community, the distribution was aggregate $(\mathrm{V} / \mathrm{M}>1)$. The same results were observed when considering every ectoparasite species, with some exceptions 


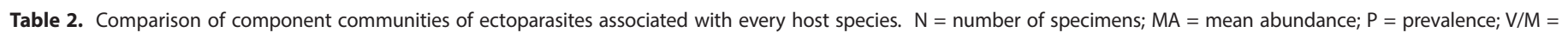
aggregation index.

\begin{tabular}{|c|c|c|c|c|c|c|c|c|c|c|c|c|c|c|c|c|}
\hline \multirow[b]{2}{*}{ Ectoparasites } & \multicolumn{4}{|c|}{ Necromys lasiurus $(n=61)$} & \multicolumn{4}{|c|}{ Akodon philipmyersi $(n=13)$} & \multicolumn{4}{|c|}{ Oligoryzomys flavescens $(n=7)$} & \multicolumn{4}{|c|}{ Oligoryzomys nigripes $(n=5)$} \\
\hline & $\mathrm{N}$ & $\mathrm{P}$ & MA & $\mathrm{V} / \mathrm{M}$ & $\mathrm{N}$ & $\mathrm{P}$ & MA & $\mathrm{V} / \mathrm{M}$ & $\mathrm{N}$ & $\mathrm{P}$ & MA & $\mathrm{V} / \mathrm{M}$ & $\mathrm{N}$ & $\mathrm{P}$ & MA & $\mathrm{V} / \mathrm{M}$ \\
\hline Androlaelaps fahrenholzi & 78 & 32.80 & 1.28 & 7.07 & 16 & 46.2 & 1.23 & 2.46 & & & & & & & & \\
\hline Androlaelaps rotundus & 366 & 83.61 & 6.00 & 6.22 & & & & & & & & & & & & \\
\hline Androlaelaps ulysespardinasi & & & & & 204 & 100 & 15.69 & 4.11 & & & & & & & & \\
\hline Gigantolaelaps wolffsohni & & & & & & & & & 6 & 42.9 & 0.86 & 1.33 & 15 & 100 & 3.0 & 0.67 \\
\hline Laelaps manguinhosi & & & & & & & & & 6 & 14.3 & 0.86 & 6.00 & & & & \\
\hline Laelaps paulistanensis & & & & & & & & & 10 & 57.1 & 1.42 & 1.83 & 46 & 100 & 9.2 & 4.59 \\
\hline Mysolaelaps parvispinosus & & & & & & & & & 12 & 57.1 & 1.71 & 2.67 & 23 & 80 & 4.6 & 2.78 \\
\hline Polygenis tripus & 47 & 36.70 & 0.77 & 4.34 & & & & & & & & & 1 & 20 & 0.2 & 1.00 \\
\hline Polygenis sp. & & & & & 2 & 7.7 & 0.15 & 2.00 & & & & & & & & \\
\hline Amblyomma ovale & 2 & 3.30 & 0.03 & 0.98 & & & & & & & & & & & & \\
\hline Ectoparasites total $(N=385)$ & 492 & 88.5 & 8.11 & 7.75 & 222 & 100 & 17.08 & 4.12 & 34 & 85 & 4.86 & 3.32 & 67 & 100 & 13.4 & 2.35 \\
\hline
\end{tabular}

in ticks and $P$. tripus collected from $O$. nigripes. In these cases randomless distribution $(\mathrm{V} / \mathrm{M}=1)$ were shown.

\section{Discussion}

In the present study, 10 ectoparasite species were identified parasitizing four sigmondontine species in southern Misiones Province in Argentina. With the exception of Polygenis sp., probably a new species deserving further study, the remaining species were previously reported for Argentina. Out of them, the following five are mentioned for the first time for the northeastern: A. rotundus, G. wolffsohni, $L$. manguinhosi, L. paulistanensis, and $P_{\text {. }}\left(P_{\text {. }}\right.$ ) tripus (Lareschi and Mauri 1998; Lareschi et al. 2016). Previously, the following mites and fleas have been mentioned parasitizing sigmodontines in Misiones Province: Adoratopsylla (Adoratopsylla) antiquorum antiquorum (Rothschild) (Ctenophthalmidae) and Polygenis (Polygenis) rimatus (Jordan; Rhopalopsyllidae, Rhopalopsyllinae), both from Abrawayaomys chebezi Pardiñas, Teta and D'Elía, A. fahrenholzi from A. philipmyersi and A. chebezi; Androlaelaps misionalis Lareschi from Akodon montensis Thomas, and M. parvispinosus from Oligoryzomys sp. (Lareschi 2010, 2011; Lareschi and Mauri 1998; Pardiñas et al. 2016). Thus, the results obtained increase to ten the biodiversity of ectoparasites associated with sigmodontines in Misiones Province.

Although the number of captured specimens of some species is low, the accumulated curves suggest that the specific ectoparasite richness reported is representative of most of every component community. The purpose of the study is more descriptive than analytical and is the first study on ectoparasites of rodents from northeastern Argentina that considers usual ecological parameters in parasitology. We consider that in this sense, our results are novel.

Considering every ectoparasite high taxa, only mites were associated with the four host species. In addition, mites were dominant, and the most prevalent and specious taxa. These results are in agreement with studies from central Argentina and Brazil (e. g., Linardi et al. 1991;
Barros-Battesti et al. 1998; Lareschi et al. 2007; Lareschi and Krasnov 2010; Sponchiado et al. 2015; Liljesthröm and Lareschi 2018). On the contrary, dominance of mites was not so remarkable observed in Argentinean Chaco (Nava and

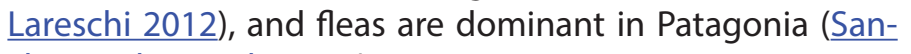
chez and Lareschi 2018).

A tendency toward host aggregation was observed for most of the ectoparasites. Out of 10 ectoparasite species identified in the present study, five were collected from a unique host species, and so, species richness varied between three and four in every component community. Core species, characterized by high prevalence and abundance (Bush et al. 1997), was detected in every community.

Every mite-host associated reported herein was previously reported for other areas. Androlaelaps ulysespardinasi and $A$. rotundus, belong to the Androlaelaps rotundus species group, which includes host specific species associated with different akodontine rodents (Lareschi and Galliari 2014; Lareschi 2018). Laelaps manguinhosi, L. paulistanensis, Mysolaelaps spp., and Gigantolaelaps spp. were reported mainly parasitizing oryzomines (Furman 1972; Lareschi and Mauri 1998). On the contrary, usually fleas and nymphs of ticks are not host specific (Linardi and Guimarães 2000; Lareschi et al. 2016; Nava et al. 2017). Among the genera of fleas included into the family Rhopalopsyllidae, Polygenis Jordan is the largest and most widely distributed, parasitizing mainly a broad range of sigmodontine rodents (Linardi and Guimarães 2000; Lareschi et al. 2016). Herein, P. (P.) tripus and Polygenis sp. were identified exclusively associated with $N$. lasiurus and A. philipmyersi, respectively. Further studies are necessary to understand these host-parasite associations.

In the same way, nymphs of ticks were only associated to N. lasiurus, although this relationship seems to be hazardous $(\mathrm{V} / \mathrm{M}=0.98)$. Amblyomma ovale has a wide distribution from southern United States to northern Argentina. Our findings are consistent with literature, since larvae and nymphs of $A$. ovale have the ability to parasitize a wide variety of hosts, including small rodents and birds, in order to increase the 
probability to reach the adult stage, which parasitize Carnivora (Nava et al. 2017).

In the last years for the northeast of Argentina, new species of mites and the unknown males of these species were described (Lareschi 2010, 2011, 2018). These studies suggest that the diversity of the area is underestimated and that more studies are needed to know its biodiversity.

In addition, $A$. ovale is a common parasite of dogs in rural and forested areas, and the records of $A$. ovale adults biting humans in South America are numerous. Besides, this tick species has capacity to transmit Hepatozoon canis, the causative agent of a serious dog disease, and it is also a potential vector of the human pathogen Rickettsia sp. strain Atlantic rainforest (Nava et al. 2017). Other ectoparasites might play an important role in epizootic diseases and their perpetuation among those rodents (Morand et al. 2006). Such is the case of Polygenis spp., (Linardi and Guimarães 2000), and Androlaelaps spp. (Lareschi and Mauri 1998; González et al. 2005; Chaisiri et al. 2015).

Since some of the ectoparasites identified may play a role in the transmition of pathogens, the results obtained contribute to a better understanding of the ectoparasitehost relationship, which may have epidemiological implications.

\section{Acknowledgments}

We thank Ernesto Krauczuck, Patricia Sandoval and Cristina Bulher from Dirección de Biodiversidad and Dirección General de Ecología y Calidad Ambiental of the Ministerio de Ecología y Recursos Naturales Renovables (MEyRNR) of the province of Misiones, Argentina, for their assistance and permission for the development of this research. To Ulyses Pardiñas (Instituto de Diversidad y Evolución Austral, Argentina) and Carlos Galliari (CEPAVE) for the taxonomic identification of rodents; to Carlos Galliari for his help with ecological analyses; to Santiago Nava (Instituto Nacional de Tecnología Agropecuaria, Estación Experimental Agropecuaria Rafaela, Argentina) for the taxonomic identification of ticks; to Erika Cuellar Soto (Centro Regional de Investigaciones Científicas y Transferencia Tecnológica de La Rioja, Argentina), María del Rosario Robles (CEPAVE), and Juliana Notarnicloa (Instituto de Biología Subtropical, Misiones, Argentina) for their help in fieldwork; to María Laura Morote (CEPAVE) for the edition of figures. This research was supported by Agencia Nacional de Promoción Científica y Tecnológica (PICT 2015-1564) and Universidad Nacional de La Plata, Argentina (N854) (both to M. Lareschi).

\section{Literature cited}

Barros-Battesti, D. M., M. Arzua, P. M. Linardi, J. R. Botelho, and I. J. Sbalqueiro. 1998. Interrelationship between ectoparasites and wild rodents from Tijucas do Sul, State of Paraná, Brazil. Memórias do Instituto Oswaldo Cruz 93:719-725.

Begon, M., J. L. Harper, And C. R. Towsend. 1988. Ecología: individuos, poblaciones y comunidades. Ediciones Omega, Barcelona.
Burkart, R., N. O. Bárbaro, R. O. Sánchez, and D. A. Gómez. 1999. Eco-Regiones de la Argentina. Administración de Parques Nacionales. Programa Desarrollo Institucional Ambiental, Buenos Aires, Argentina.

Bush, A. O., K. D. Lafferty, J. M. Lotz, and A. W. Shostak. 1997. Parasitology meets ecology on its own terms: Margolis et al. revisited. Journal of Parasitology 83:575-583.

Chaisiri, K., J. W. McGarry, S. Morand, and B. L. Makepeace. 2015. Symbiosis in an overlooked microcosm: a systematic review of the bacterial flora of mites. Parasitology 142:1152-1162.

FuRman, D. P. 1972. Laelapid mites (Laelapidae: Laelapinae) of Venezuela. Brigham Young University Science Bulletin, Biological Series 27:1-58.

Galliarl, C. A., And F. GoIn. 1993. Conservación de la Biodiversidad en la Argentina: el caso de los mamíferos. Pp. 367-400 in Elementos de Política Ambiental (Goin, F., and R. Goñi, eds.). Honorable Cámara de Diputados de la provincia de Buenos Aires, Argentina.

González, A., M. Lareschi, and C. de Villalobos. 2005. Capítulo 1. Acari (excepto Ixodida)- Ácaros. Pp. 7-14 in Artrópodos de interés médico en Argentina (Salomón, D., ed.). Serie enfermedades Transmisibles. Publicación Monográfica 6. Fundación Mundo Sano, Argentina.

Hammer, O., D. A. T. Harper, and P. D. Ryan. 2001. PAST: Paleontological Statistics Software Package for Education and Data Analysis. Palaeontologia Electronica 4:1-19.

KIM, K. CH. 1985. Coevolution of Parasitic Arthropods and Mammals. London University Press, London, U.K.

Krasnov, B. 2008. Functional and Evolutionary Ecology of Fleas: A Model for Ecological Parasitology. Cambridge University Press, Cambridge, U. K.

Lanzone, C., C. A. Labaroni, A. Formoso, L. M. Buschiazzo, F. Da Rosa, AND P. TETA. 2018. Diversidad, sistemática y conservación de roedores en el extremo sudoccidental del Bosque Atlántico Interior. Revista del Museo Argentino de Ciencias Naturales n. s. 20:151-164

LARESCHI, M. 2010. A new species of Androlaelaps Berlese, 1903 (Acari: Parasitiformes) parasitizing an akodontine rodent (Cricetidae, Sigmodontinae) in Northeastern Argentina. Systematic Parasitology 76:199-203.

LARESCHI, M. 2011. Laelapid mites (Parasitiformes, Gamasida) parasites of Akodon philipmyersi (Rodentia, Cricetidae) in the Northern Campos Grasslands, Argentina, with the description of a new species. Journal of Parasitology 97:795-799

LARESCHI, M. 2018. Description of the males of Androlaelaps misionalis and Androlaelaps ulysespardinasi (Acari: Parasitiformes: Laelapidae) parasitic of sigmondontine rodents from northeastern Argentina. Journal of Parasitology 104:372-376.

LARESCHI, M., AND C. Galliari. 2014. Multivariate discrimination among cryptic mites of the genus Androlaelaps (Acari: Mesostigmata: Laelapidae) parasitic of sympatric akodontine rodents (Cricetidae: Sigmodontinae) in northeastern Argentina: possible evidence of host switch followed by speciation. Experimental and Applied Acarology 64:479-499. LARESCHI, M., AND B. KRASNov. 2010. Determinants of ectoparasite assemblage structure on rodent hosts from South American marshland: The effects of host species, locality and season. Medical and Veterinary Entomology 24:284-292. 
LARESCHI, M., AND R. MaURI. 1998. Capítulo 58: Dermanyssoidea. Pp. 581-590 in Biodiversidad de artrópodos argentinos. Una perspectiva biotaxonómica (Morrone, J. J., and S. Coscarón, dirs.). Ediciones Sur, Argentina.

Lareschi, M., J. Notarnicola, S. Nava, And G. Navone. 2007. Parasite community (Arthropods and Filarioids) associated with wild rodents from the marshes of La Plata River, Argentina. Comparative Parasitology 74:141-147.

Lareschi, M., J. Sanchez, And A. Autino. 2016. A review of the fleas (Insecta- Siphonaptera) from Argentina. Zootaxa 4103:239258.

LiLjesthrom, G. ANd M. LARESCHI. 2018. Predicting species richness of ectoparasites of wild rodents from the Río de la Plata coastal wetlands, Argentina. Parasitology Research 117:2507-2520.

Linardi, P. M., J. R. Botelho, A. Ximenez, and C. R. Padovani. 1991. Notes on Ectoparasites of Some Small Mammals from Santa Catarina State, Brazil. Journal of Medical Entomology 28:183-185.

LinARDI, P. M., AND R. L. Guimarães. 2000. Sifonápteros do Brasil. Ed. MZUSP, FAPESP. São Paulo, Brasil.

MarShall, A. G. 1981. The ecology of ectoparasitic insects. Academic Press. New York, U. S. A.

Martins, T. F., M. B. Labrunaa, A. J. Mangold, M. M. Cafrune, A. A. Guglielmone, And S. NAvA. 2014. Taxonomic key to nymphs of the genus Amblyomma (Acari: Ixodidae) in Argentina, with description and redescription of the nymphal stage of four Amblyomma species. Ticks and Tick-borne Diseases 5:753-770.

Morand, S., B. Krasnov, And R. Poulin. 2006. Micromammals and Macroparasites. From Evolutionary Ecology to Management. Tokyo, Japan.

NAVA, S., AND M. LARESCHI. 2012. Ecological characterization of a community of arthropods parasitic of sigmodontine rodents in the Argentinean Chaco. Journal of Medical Entomology 49:1276-1282.

Nava, S., J. Venzal, D. González-Acuña, T. Martins, and A. Guglielmone. 2017. Ticks of the Southern Cone of America. Diagnosis, Distribution, and Hosts with Taxonomy, Ecology and Sanitary Importance. Academic Press. New York, U. S. A.

Pardiñas, U. F. J., G. D’Elía, S. Cirignoli, and P. Suárez. 2005. A new species of Akodon (Rodentia, Cricetidae) from the northern Campos grasslands of Argentina. Journal of Mammalogy 86:462-474.

Pardiñas, U. F. J., P. Teta, M. Lareschi, and C. A. Galliari. 2016. The second trapped specimen of Abrawayaomys chebezi (Rodentia, Sigmodontinae): new data about a poorly known sylvan rodent and its first record in Brazil. Mammalia 80:341348.

Patton, J. L., U. F. J. Pardiñas, and G. D’Elía. 2015. Mammals of South America, Volume 2 - Rodents. University of Chicago Press, Chicago, Illinois, U. S. A.

RózsA, L., J. REICZIGEL, AND G. MAJOROS. 2000. Quantifying parasites in samples of hosts. Journal of Parasitology 86:228-232.

SANCHEZ, J., AND M. LARESCHI. 2018. Ecological approach of the fleas associated with Sigmodontine rodents from Patagonia, Argentina. Bulletin of Entomological Research 1-12.

Smit, F. G. A. M. 1987. An illustrated Catalogue of the Rothschild Collection of fleas (Siphonaptera) in the British Museum (Natural History). Volume VII. Malacopsylloidea. British Museum (Natural History), Oxford University Press. Oxford, U. K.
Sponchiado, J., L. M. Geruza, G. A. Landulfo, F. C. Jacinavicius, D. M. Barros-Battesti, and N. C. Cáceres. 2015. Interaction of ectoparasites (Mesostigmata, Phthiraptera and Siphonaptera) with small mammals in Cerrado fragments, western Brazil. Experimental and Applied Acarology 66:369-381.

Associated editor: Jesús Fernández

Submitted: January 13, 2019; Reviewed: January 29, 2019;

Accepted:March 6, 2019; Published on line:March 21, 2019. 